Egypt. Acad. J. Biolog. Sci., 5(1): 97 - 100 (2013)

Email: egyptianacademic@yahoo.com

Received: 25 / 6 / 2013
C. Physiology \& Molecular Biology

ISSN: 2090-0767

www.eajbs.eg.net

\title{
Enzyme Inhibition (AChE) in Brain of Oreochromis mossambicus due to Pesticidal Pollution of Herbicide "Pursuit"
}

\author{
Farhina Pasha \\ Department of Biology, Girls Science Section, University of Tabuk, Kingdom of \\ Saudi Arabia
}

\begin{abstract}
In the present investigation, the effect of three sublethal concentrations of Pursuit, that is, $63.7 \mathrm{ppm}, 85 \mathrm{ppm}$, and $127.5 \mathrm{ppm}$ in Oreochromis mossambicus was studied. Pursuit inhibited acetyl cholinesterase in the brain of Oreochromis mossambicus by increasing the $\mathrm{K}_{\mathrm{m}}$ and $\mathrm{V}_{\max }$, thereby acting as a mixed inhibitor. The assay of brain AChE is thus useful for monitoring pesticide toxicity of fish.
\end{abstract}

Keywords: Acetyl cholinesterase, Oreochromis mossambicus, Pursuit and Mixed inhibitor.

\section{INTRODUCTION}

The unscrupulous use of pesticides, approximately 19,000 to 20,000 pesticides, which broadly include; herbicide, insecticide, and fungicide are, currently approved for release by the U.S. Environmental Protection Agency (EPA), with the advent of "Green Revolution" (Boon and Bridge 2003). Acetylcholine is released from preganglion neurons of parasympathetic division of autonomic nervous system. It is a unanimously accepted fact that hydrolysis of Acetylcholine (ACh) to choline and acetic acid is catalyzed by enzyme cholinesterase in animal system. The enzyme prevents accumulation of excessive acetylcholine at cholinergic synapse and at neuromuscular junction (Konar, 1979; Kollberg, 1976). Quantitative estimation of acetyl cholinesterase (AChE) is taken as a good indicator of the extent of pesticide pollution in animals. Enhanced ACh accumulation results in affecting metabolism, muscle coordination, and irregular transmission of impulse and ultimate death of the animal. The test pesticide pursuit ( $10 \% \mathrm{st}$ ) is a herbicide (a carbamate compound) used extensively for effective control of annual grasses, sludge, and broad leaf weeds in soyabean and groundnut crops, and so on. Its main chemical IMAZETHAPYR $\left(\mathrm{C}_{15} \mathrm{H}_{22} \mathrm{~N}_{4} \mathrm{O}_{3}\right)$ blocks protein synthesis. Therefore, the present study was undertaken to investigate long term exposure of pesticides pursuit on brain AChE enzyme kinetics of an exotic carp Oreochromis mossambicus which may be used as a diagnostic tool to assay toxicity of carbamate compounds to vertebrates and as a controlling measure to check the growth of Oreochromis mossambicus which is commonly known as a neuscence fish, as it destroys the indigenous fauna.

\section{MATERIAL AND METHOD}

Healthy fingerlings of Oreochromis mossambicus of $5 \mathrm{~cm}$ length of both sexes were kept in glass aquaria and acclimatized to laboratory conditions for two weeks. They were fed daily, until two days prior to acute and chronic exposure of pursuit (American Cynamide Co. USA). LC $_{50}$ value of pursuit for 96 hrs was determined by Doudroff et al., (1951) and estimated to be $0.51 \mathrm{ml} / \mathrm{L}$. Three sublethal concentrations were taken from 2/3rd of $\mathrm{LC}_{50}$ value and were $63.7 \mathrm{ppm}, 85 \mathrm{ppm}$, and $127.5 \mathrm{ppm}$. Group of 10 fingerlings was exposed to 3 sublethal concentrations for $96 \mathrm{hrs}$ and control was also maintained for the same duration. At the end of the experiment, 
the control and experimental fishes were dissected and brain was removed. 5\% tissue homogenate was prepared in icecold $0.25 \mathrm{M}$ sucrose solution and centrifuged at $12000 \mathrm{rpm}$ for 7 minutes. AChE activity was measured spectrophotometrically at $540 \mathrm{~nm}$ by the method of Metcalf (1951) using AchI as substrate. Protein estimation was done according to Lowry's et al. method (1951) using Bovine serum albumin as standard. $\mathrm{K}_{\mathrm{m}}$ and $\mathrm{V}_{\max }$ were calculated by applying Line weaver Burk plot for enzyme kinetic study.

\section{RESULTS}

The kinetic parameters $\mathrm{K}_{\mathrm{m}}$ and $\mathrm{V}_{\max }$ of enzyme AChE were undertaken for pursuit toxicity (acute exposure of 96 hrs). The three sublethal concentrations were $63.7 \mathrm{ppm}, 85 \mathrm{ppm}$, and $127.5 \mathrm{ppm}$ of $\mathrm{LC}_{50}, 96$ hrs. The calibration standard graph was made to access $K_{m}$ values .In Control fingerlings, the $\mathrm{K}_{\mathrm{m}}$ value of brain was observed as $4.78 \times 10^{-3}$ at $63.7 \mathrm{ppm}$, and the $\mathrm{K}_{\mathrm{m}} \times 10^{-3} \mathrm{M}$ was $6.24 \times 10^{-3} \mathrm{M}$, further increased to $12.47 \times 10^{-3} \mathrm{M}$ at 85 $\mathrm{ppm}$ and was maximum at $127.5 \mathrm{ppm}$, i.e., $18.34 \times 10^{-3} \mathrm{M}$. The $\mathrm{V}_{\max }$ was found to be highest at $127.5 \mathrm{ppm}$ as 14.3 Absorbance/mg proteins/30 min which decreased to $9.10 \mathrm{~A} / \mathrm{mg}$ protein $/ 30 \mathrm{~min}$ at $85 \mathrm{ppm}$. The $\mathrm{V}_{\max }$ at $63.7 \mathrm{ppm}$ was observed as $5.0 \mathrm{~A} / \mathrm{mg}$ protein/30 min and $\mathrm{V}_{\max }$ for control fingerlings were observed as $1.22 \mathrm{~A} / \mathrm{mg}$ protein/30 min (Table1 and Fig. 1).

Table 1: Acute effect of different concentrations of Pursuit on kinetic parameters $K_{m}$ and $V_{\max }$ of AChE of Brain of O. mossambicus (Substrate used was AChI).

\begin{tabular}{|c|c|c|c|}
\hline \multicolumn{3}{|c|}{ Pursuit } & KINETIC PARAMETERS \\
\hline Concentrati & \multicolumn{2}{|l|}{$\mathrm{K}_{\mathrm{m}} \times 10^{-3} \mathrm{M}$} & $\mathrm{V}_{\max }$ \\
\hline \multicolumn{3}{|l|}{ (ppm) } & Absorbance/mg protein/ \\
\hline \multicolumn{3}{|l|}{96 hrs. } & $30 \mathrm{~min}$. \\
\hline \multicolumn{3}{|c|}{ Control $4.78 \times 10^{-3}$} & 1.22 \\
\hline $63.7 \mathrm{ppm}$ & $6.24 \times 10^{-3}$ & \pm 0.269 & 5.0 \\
\hline $85.0 \mathrm{ppm}$ & $12.47 \times 10^{-3}$ & \pm 0.48 & 9.10 \\
\hline $127.5 \mathrm{ppm}$ & $18.34 \times 10^{-3}$ & \pm 0.16 & 14.31 \\
\hline
\end{tabular}

$127.5 \mathrm{ppm} \square 85.0 \mathrm{ppm} \Delta 63.7 \mathrm{ppm}$ 它 control

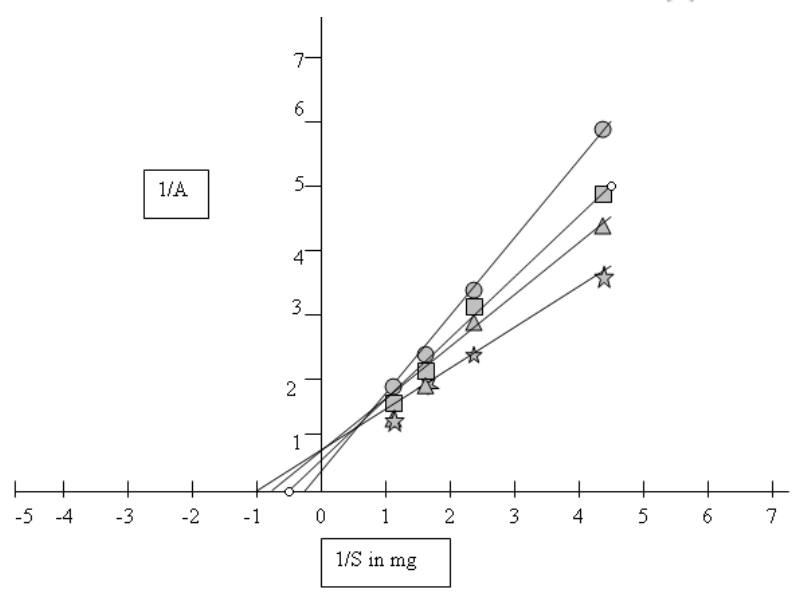

Fig. 1: Line weaver burk plot of inhibitory effect of 63.7; 85.0; and 127.5 ppm PURSUIT on AChE on brain of O.mossambica treated for 96 hrs. (S is the concentration of AChI). 
The slopes obtained from tissues was observed as $7.48 \times 10^{-3} \mathrm{M}$ uninhibited (controlled) and inhibited against a control value of $4.76 \times 10^{-3} \mathrm{M}$. (treated) enzymes intersected at different The $\mathrm{K}_{\mathrm{m}} \times 10^{-3} \mathrm{M}$ reached $8.9 \times 10^{-3} \mathrm{M}$ ordinates of Michaels menten constant, after 30 days at $63.7 \mathrm{ppm}$ concentration showed a significant increase in toxic against a control value of $4.76 \times 10^{-3} \mathrm{M}$ conditions at 96 hrs.

The fingerlings were exposed for 15 days and 30 days, for chronic exposure, the fingerlings were exposed to minimum concentration of pursuit, i.e., $63.7 \mathrm{ppm}\left(1 / 8\right.$ th of $\mathrm{LC}_{50}$ for $\left.96 \mathrm{hrs}\right)$. The fingerlings were exposed to $63.7 \mathrm{ppm}$ pursuit for 15 days, the $\mathrm{K}_{\mathrm{m}}$ in brain on the 30th day. Fingerlings exposed to $63.7 \mathrm{ppm}$ values gave a $\mathrm{V}_{\max }$ of $4.5 \mathrm{~A} / \mathrm{mg}$ protein/30 min for 15 days and 30 days of chronic exposure to pursuit. While the $\mathrm{V}_{\max }$ in control fingerlings was observed as $1.25 \mathrm{~A} / \mathrm{mg}$ protein/30 min (Table 2 and Figure 2) on the 15 th and the $30^{\text {th }}$ day.

Table 2: Chronic effect of different concentrations of Pursuit on kinetic parameters $K_{m}$ and $V_{\max }$ of AChE of Brain of O. mossambicus (The Substrate use was AChI).

\begin{tabular}{|c|c|c|c|}
\hline \multirow[b]{2}{*}{ Pursuit Concentration (ppm) } & \multicolumn{3}{|c|}{ KINETIC PARAMETERS } \\
\hline & \multicolumn{2}{|c|}{$\mathrm{K}_{\mathrm{m}} \times 10^{-3} \mathrm{M}$} & $\mathrm{V}_{\max }$ Absorbance/mg Protein/30min \\
\hline \multicolumn{4}{|l|}{15 Days } \\
\hline Control & $4.76 \times 10^{-3}$ & \pm 0.28 & 1.25 \\
\hline $63.7 \mathrm{ppm}$ & $7.48 \times 10^{-3}$ & \pm 0.52 & 4.5 \\
\hline \multicolumn{4}{|l|}{30 Days } \\
\hline Control & $4.76 \times 10^{-3}$ & \pm 0.46 & 1.25 \\
\hline $63.7 \mathrm{ppm}$ & $8.9 \times 10^{-3}$ & \pm 0.52 & 4.5 \\
\hline Control & $4.76 \times 10^{-3}$ & \pm 0.28 & 1.25 \\
\hline
\end{tabular}

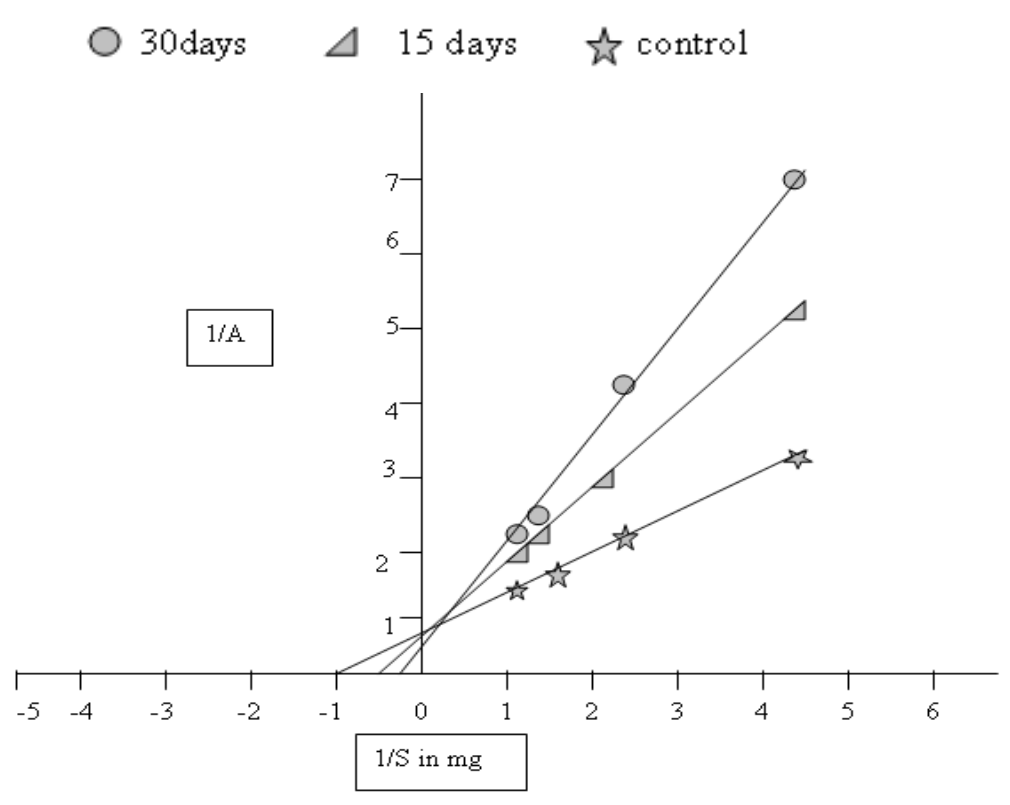

Fig. 2: Line weaver burk plot of inhibitory effect of $63.7 \mathrm{ppm}$ Pursuit on AChE on brain of O.mossambica treated for 15 and 30 days. ( $\mathrm{S}$ is the concentration of AChI). 


\section{DISCUSSION}

The Line weaver Burk plots of the present investigations revealed the acute exposure of pursuit for 96 hrs at three sublethal concentrations, i.e., $63.7 \mathrm{ppm}$, $85 \mathrm{ppm}$, and $127.5 \mathrm{ppm}$, and reported an increase in $\mathrm{K}_{\mathrm{m}} \times 10^{-3} \mathrm{M}$ from $4.78 \times 10^{-3}$ $\mathrm{M}$ in control to $63.7 \mathrm{ppm}$, 85ppm, and $127.5 \mathrm{ppm}$ concentrations where $\mathrm{K}_{\mathrm{m}} \mathrm{X}$ $10^{-3} \mathrm{M}$ increased to $6.24 \times 10^{-3}, 12.47 \mathrm{x}$ $10^{-3} \mathrm{M}$ and $18.34 \times 10^{-3} \mathrm{M}$, respectively, in Brain. The $\mathrm{V}_{\max }$ at control $22 \mathrm{~A} / \mathrm{mg}$ protein/30 min and at $63.7 \mathrm{ppm}, 85 \mathrm{ppm}$, and $127.5 \mathrm{ppm}$ as $5.0 \mathrm{~A} / \mathrm{mg}$ protein/30 min, $9.10 \mathrm{~A} / \mathrm{mg}$ protein/30 min, and 14.3 $\mathrm{A} / \mathrm{mg}$ protein/30 min, respectively. The slope obtained from uninhibited and inhibited enzymes intersect at different ordinates of Michaelis Menten constant showed a significant increase in toxic conditions at 96 hrs .Our results are in conformity with Basha Mohideen and Sailbala (1989), and Coppage and Mathews (1974), although with different fish species and with Rao et al., (1984) and Rao and Rao (1989), Tembhre and Kumar (1995), who also reported similar trends of mixed inhibition. Moreover Oreochromis mossambicus (Tilapia), which has created a serious problem for survival of indigenous fauna, can be controlled to certain extent by this carbamate compound pursuit as the fish is hardy and resistant to majority of toxicants pursuit being a carbamate and a mixed inhibitor is strong toxicant and its recovery is far more difficult.

\section{REFERENCES}

Bashamohideen, M. and Sailbala, T. (1989). AChE activity in the tissue of Cyprinus carpio subjected to the sublethal exposure of malathion, J. Environ. Biol., 10(1): 51-57.

Carter, F. L. (1971). In vivo studies of brain acetylcholinesterase inhibition by organophosphate and carbamate insecticides in fish.Ph. D. Dissertation,
Louisiana State Univ. Baton, Rouge, Louisiana.

Coppage, D.L.; Mathews, E.; Garv, H. Cook and Knight. J. (1974). Brain acetylcholinesterase inhibition in fish as a diagnosis of environmental poisoning by malathion pesticide, Biochem. and physiol. 5: 536-542.

Coppage, D.L.; Mathews, E.; Garv, H. Cook and Knight, J. (1975). Brain acetylcholinesterase inhibition in marine teleost during lethal and sublethal exposure to 2-dibromo-2,2dichloroethyl dimethyle phosphatein sea water. Toxicol. Appl. Pharmacol, 31:128-129.

Duodoroff, P.; Anderson, B. G.; Burdwick, G. E.; Galtsaff, P.S.; Hart, W. B.; Patrick, R.; Strong, E. R.; Surber, E. W. and Vanhern, W. M. (1951). Standard methods for determination of $\mathrm{LC}_{50}$ values, Sew. Indust. Water, 23:130.

Konar, S. K. (1979). Pesticides and aquatic ecosystem, Indian Jour. Fish , 22:8085.

Lowry, O. H.; Rosenbrough, N. J. and Randall, R. J. (1951). protein measurement with Folinphenol reagent, J. Biol. Chem., 193:265-275.

Metcalf, R. L. (1951). Methods in biochemical Analysis (D.Click Ed.), Intrinsic Publishers Inc. New York,1.

Satyadevan, S. (1994). Cholinesterase system of brain of Cyprinus carpio; Biochemical kinetics and histopathological study, Ph. D. Thesis, Barkatullah University. Bhopal.

Shiva Pratap Rao, K., Kabeer Ahmad, I. and Rama Rao, K. V. (1982). Impact of methyl parathion on lactate dehydrogenase isozymes of a teleost Tilapia mossambica_(Peters) Indian J. Fish, 29:185.

Tembhre, M. and Kumar, S. (1995). Effect of sublethal concentrations of methylamine on AChE activity and enzyme kinetics of alimentary canal of Cyprinus carpio, Indian J. Spect., 6(2): 39-42. 